\title{
STRATEGI PENINGKATAN KUALITAS PENDIDIKAN DI MADRASAH ALIYAH KABUPATEN SIDRAP: Tinjauan Implementasi Kurikulum Tingkat Satuan Pendidikan
}

\author{
Ali Rahim \\ Madrasah Aliyah DDI Tellulimpoe Kab. Sidrap \\ Jl. Latahang Desa Polewali Kec. Tellulimpoe Kab. Sidrap \\ Email: haris.jawad@ymail.com
}

\begin{abstract}
Abstrak:
Penelitian ini bertujuan untuk menganalisis strategi peningkatan kualitas pendidikan Madrasah Aliyah di Kabupaten Sidrap ditinjau dari segi implementasi kurikulum tingkat satuan pendidikan. Jenis penelitian adalah penelitian kualitatif. Metode pengumpulan data adalah; observasi, wawancara, observasi dan penelusuran referensi dengan teknik analisis data reduksi data, penyajian data dan verifikasi data. Hasil penelitian menunjukkan; 1) Umumnya guru MA sudah mengimplementasikan KTSP. 2) Sebagian guru tidak maksimal karena kondisi sarana yang tidak mendukung. 3) Faktor pendukung yaitu; manajemen kepala madrasah, kurikulum, kompetensi guru, anggaran pendidikan, optimalisasi kerjasama dengan masyarakat. 4) Faktor penghambat; kurangnya sarana prasarana, guru mengajar tidak sesuai dengan latar belakang pendidikannya, rendahnya kesejahteraan guru. 5) Untuk mengatasi faktor penghambat adalah; meningkatkan kualitas sarana prasarana. 6) Bentuk strategi yaitu; peningkatan kualitas manajemen kurikulum dan program pengajaran, peningkatan kompetensi guru, peningkatan kesejahteraan guru, peningkatan prestasi akademik siswa, terpenuhinya kebutuhan sarana dan prasarana, peningkatan kualitas pelaksanaan tugas kepala madrasah, peningkatan kualitas ketakwaan kepada Allah swt. serta akhlak mulia, dan meningkatkan manajemen hubungan madarasah dengan masyarakat.
\end{abstract}

\begin{abstract}
:
This study aimed to analyze the strategy of improving the quality of education in Madrasah Aliyah Sidrap viewed from of the implementation of the educational unit level curriculum. This type of research was qualitative. The data collection methods used were observation, interviews, documentation and the data analysis techniques used were data reduction, data display and data verification. The results of the research showed that; 1) The teachers of MA in general had implemented the educational unit level curriculum. 2) Most of the teachers were not optimal in implementing it because the condition, did not support. 3) The supporting factors were the headmaster management, the curriculum, the teachers' competence, the educational budget, the optimization of cooperation with the community. 4) The inhibiting factors were lack of infrastructure, the teachers who teach were not in accordance with their educational background, and lack of teachers' welfare. 5) The efforts conducted to overcome the inhibiting factor was to improve the quality of infrastructure. 6) The kind of strategies used were, improving the quality of the curriculum management and the teaching programs, increasing the teachers' competence, improving the welfare of the teachers, increasing students' achievement, fulfilling facilities and infrastructure, improving the quality of implementation of headmaster's role, improving the quality of devotion to God Almighty and noble character, and improving the management of the Islamic school relationship with the community.
\end{abstract}

Kata Kunci:

Strategi Pembelajaran, Madrasah, KTSP 
MADRASAH, sebagai bagian dari sistem pendidikan nasional, tidak luput dari berbagai masalah. Permasalahan mendasarnya adalah madrasah seakan-akan tersisih dari mainstream pendidikan nasional secara umum baik dari sisi kualitas, manajemen termasuk masalah kurikulum. Meskipun demikian, madrasah mempunyai potensi untuk berkembang karena nilai-nilai yang diusungnya melekat dengan nilai-nilai budaya bangsa.

Terjadinya perubahan wawasan pembangunan dalam bentuk otonomi daerah dari sentralistik menjadi desentralistik menjadikan pendidikan di Indonesia berada dalam suasana baru pengelolaan dan pengembangan kurikulum termasuk kurikulum madrasah, terlebih lagi setelah diberlakukan Kurikulum Tingkat Satuan Pendidikan (KTSP). Perubahan tersebut meliputi perpindahan tanggung jawab dalam pengambilan keputusan atas pengembangan kurikulum dari yang bersifat terpusat oleh pemerintah menjadi kewenangan yang ada pada masing-masing sekolah.

Meningkatkan kualitas pendidikan apabila ditinjau dari sistem pendidikan nasional, maka faktor dan unsur-unsur yang mempengaruhi adalah faktor kurikulum, faktor guru, faktor sarana dan prasarana, faktor waktu, faktor uang, faktor tujuan, faktor metode, dan faktor lingkungan pendidikan.

Untuk merespon tuntutan masyarakat dan menjaga jati diri madrasah sebagai lembaga pendidikan Islam yang berkualitas dan memiliki ciri khas Islam, maka madrasah harus mengembangkan program seperti; memberikan nuansa Islam atau spritualisasi bidang studi umum, pengajaran bidang studi agama Islam yang bernuansa Iptek dan menciptakan suasana keagamaan di madrasah terutama dalam pembelajaran mafikibi (matematika, fisika, kimia dan biologi) yang agamis dalam perilaku siswa. ${ }^{1}$ Pengembangan kurikulum madrasah dilakukan dengan berbasis kebutuhan madrasah dan masyarakat di sekitarnya atau pengembangan kurikulum berbasis sekolah dengan meminjam Istilah Murray Print dalam bukunya Curriculum Development and Design. ${ }^{2}$

Kurikulum adalah seperangkat rencana dan pengaturan mengenai tujuan, isi, dan bahan pelajaran serta cara yang digunakan sebagai pedoman penyelenggaraan pembelajaran untuk mencapai tujuan pendidikan tertentu. Dengan kata lain, kurikulum merupakan syarat mutlak bagi pendidikan di madrasah. Kalau kurikulum merupakan syarat mutlak, hal itu berarti bahwa kurikulum merupakan bagian yang tidak terpisahkan dari pendidikan dan pengajaran. ${ }^{3}$

KTSP merupakan upaya untuk menyempurnakan kurikulum agar lebih familiar dengan guru karena kiprah guru lebih dominan terutama dalam menjabarkan standar kompetensi dan kompetensi dasar, tidak saja dalam program tertulis, tetapi juga dalam pembelajaran nyata di kelas. ${ }^{4}$

Madrasah Aliyah di Kabupaten Sidrap adalah sekolah menengah yang perlu mengadakan perkembangan kurikulum berupa KTSP untuk meningkatkan kualitas pendidikannya. Selain itu penerapan KTSP ini untuk memenuhi amanat Undang-Undang No 20 Tahun 2003 tentang Sisdiknas dan Peraturan Pemerintah No. 19 tahun 2005 SNP yang berfungsi mencapai tujuan pendidikan nasional pada umumnya, dan 
tujuan pendidikan sekolah pada khususnya. Oleh karena itu, Madrasah Aliyah di Kabupaten Sidrap perlu untuk mengembangkan KTSP. Pengembangan KTSP di Madrasah Aliyah Kabupaten Sidrap ini dimulai pada tahun 2007/ 2008 yang dilakukan secara bertahap. Dengan diadakannya pengembangan kurikulum ini diharapkan kualitas pendidikan di Madrasah Aliyah Kabupaten Sidrap mengalami peningkatan.

Hasil observasi awal pada objek penelitian menunjukkan bahwa terdapat dua bagian pokok kajian utama dalam menganalisis eksistensi Madrasah Aliyah di Kabupaten Sidrap yang perlu dilakukan yaitu: Pertama; kajian kualitas pendidikan madrasah masih kalah bersaing dengan lembaga pendidikan umum lainnya. Kedua, kualitas sarana dan prasarana, serta kualitas manajemen pendidikan madrasah.

Fenomena inilah yang memotivasi penulis untuk menganalisis tentang strategi peningkatan kualitas pendidikan Madrasah Aliyah di Kabupaten Sidrap ditinjau dari segi implementasi kurikulum tingkat satuan pendidikan.

Berdasarkan latar belakang di atas, maka permasalahan penelitian ini adalah:

1. Bagaimana implementasi Kurikulum Tingkat Satuan Pendidikan (KTSP) dalam proses pembelajaran di Madrasah Aliyah Kabupaten Sidrap?

2. Bagaimana faktor pendukung dan penghambat peningkatan kualitas pendidikan di Madrasah Aliyah Kabupaten Sidrap serta solusinya?

3. Bagaimana bentuk strategi peningkatan kualitas pendidikan di Madrasah Aliyah Kabupaten Sidrap?

\section{TINJAUAN TEORETIS}

\section{Tinjauan Umum Madrasah}

Madrasah adalah salah satu bentuk kelembagaan pendidikan Islam yang memiliki sejarah sangat panjang, pendidikan Islam itu sendiri muncul dan berkembang seiring dengan munculnya Islam itu sendiri yakni berawal dari pendidikan yang bersifat informal berupa dakwah islamiyah untuk menyebarkan Islam, terutama dalam hal yang berkaitan akidah, pendidikan Islam diselenggarakan di rumah-rumah dan masjid, kebangkitan madrasah merupakan awal dari bentuk pelembagaan pendidikan secara formal.

Madrasah, dalam Undang-Undang 20 Tahun 2003 tentang Sisdiknas itu merupakan jenis pendidikan umum. Pada pasal 17 ayat (2), Madrasah Ibtidaiyah dan Madrasah Tsanawiyah dikategorikan sebagai bentuk pendidikan dasar (setingkat dan sama dengan SD dan SLTP), sedangkan ayat (3) pasal yang sama, Madrasah Aliyah dikategorikan sebagai bentuk pendidikan menengah (setingkat dan sama dengan SMU) dan Madrasah Aliyah Kejuruan sebagai bentuk sekolah menengah kejuruan (setingkat dan sama dengan SMK).

\section{Strategi Peningkatan Kualitas Pendidikan}

\section{Pengertian Strategi}

Strategi merupakan suatu seni mempergunakan kecakapan dan sumberdaya untuk mencapai sasaran. ${ }^{5}$ Pendefinisian lainnya adalah sekumpulan pilihan program 
dalam jangka panjang untuk mencapai tujuan, kebijakan dan pelaksanaan kegiatan. Keberhasilan suatu strategi sangat ditentukan oleh sasaran atau tujuan yang ingin dicapai. Untuk membuat suatu strategi, salah satu model analisis yang sering digunakan adalah analisis SWOT. Analisis SWOT adalah identifikasi berbagai faktor secara sistematis untuk merumuskan suatu strategi. ${ }^{6}$

Strategi adalah bagian dari jenis perencanaan, karena akan menentukan tindakan-tindakan pada masa datang untuk mencapai tujuan yang diinginkan. Pada dasarnya strategi adalah penentuan cara yang harus dilakukan agar pekerjaan yang dilaksanakan memungkinkan memperoleh hasil yang optimal, efektif, dan dalam jangka waktu yang relatif singkat serta tepat menuju tercapainya tujuan yang ditetapkan.

\section{Pengertian Kualitas Pendidikan}

Dari sudut kepentingan konsumen pendidikan, jaminan kualitas merefleksikan tingkat kepuasan pelayanan dan kualitas lulusan. Sallis mendefinisikan dan mengelompokkan pelanggan pendidikan ke dalam dua kelompok besar yaitu pelanggan internal dan pelanggan eksternal. Pelanggan internal meliputi kepala sekolah, para pendidik/guru, para staf pendukung dan para pembina pendidikan. Sedangkan pelanggan eksternal ada tiga kelompok, meliputi pelanggan eksternal primer (utama) yaitu peserta didik/murid, pelanggan eksternal sekunder yaitu orang tua dan para pemimpin pemerintahan, serta pelanggan eksternal tersier yaitu pasaran kerja, pemerintah, dan masyarakat luas.

Sedangkan kualitas pendidikan ditinjau dari pelanggan eksternal sekunder dan tersier adalah apabila hasil pendidikan memberikan sumbangan positif kepada orang tua, para pemimpin pemerintah, pasar kerja, pemerintah, industri dan masyarakat luas. ${ }^{7}$ Misalnya lulusan sekolah tertentu siap untuk menerima tugas-tugas pekerjaan di perusahaan atau instansi pemerintah walaupun masih perlu bimbingan. Bagi masyarakat luas pendidikan dikatakan berkualitas apabila lulusannya tidak menimbulkan keributan seperti tawuran atau perkelahian massal. Bagi para pemimpin dan para pemerintah maka pendidikan berkualitas adalah apabila lulusan pendidikan mampu memberikan kontribusi terhadap pertumbuhan ekonomi, kesejahteraan rakyat, dan keadilan sosial.

\section{Faktor-faktor yang Berpengaruh pada Peningkatan Kualitas Pendidikan}

Adapun faktor-faktor yang berpengaruh pada peningkatan kualitas pendidikan adalah sebagai berikut: manajemen sekolah/madrasah, ${ }^{8}$ kurikulum sekolah/madrasah, ${ }^{9}$ tenaga pengajar/pendidik (guru) yang memiliki kompetensi, ${ }^{10}$ pengembangan sarana dan prasarana, ${ }^{11}$ anggaran pendidikan yang memadai, ${ }^{12}$ optimalisasi kerjasama antara pengelola pendidikan dengan orang tua siswa atau masyarakat. ${ }^{13}$

\section{Hambatan yang Dihadapi dalam Peningkatan Kualitas Pendidikan}

Ada beberapa masalah atau hambatan yang dihadapi dalam upaya peningkatan kualitas pendidikan di Indonesia adalah segala masalah selain masalah paradigma pendidikan, yang berkaitan dengan penyelenggaraan pendidikan, di antaranya yang 
terpenting adalah sebagai berikut: rendahnya kualitas sarana fisik, rendahnya kualitas guru, rendahnya kesejahteraan guru, kurangnya pemerataan kesempatan pendidikan, rendahnya relevansi pendidikan dengan kebutuhan, mahalnya biaya pendidikan.

\section{Pengertian dan Urgensi KTSP}

\section{Pengertian Kurikulum Tingkat Satuan Pendidikan (KTSP)}

KTSP adalah kurikulum operasional yang disusun dan dilaksanakan di masingmasing satuan pendidikan. Penyusunan KTSP dilakukan oleh satuan pendidikan dengan memperhatikan dan berdasarkan standar kompetensi dan kompetensi dasar yang dikembangkan oleh Badan Standar Nasional Pendidikan (BSNP). ${ }^{14}$

Berdasarkan pengertian di atas, dapat disimpulkan bahwa KTSP adalah kurikulum madrasah berupa seluruh program yang terencana yang disusun dan dikembangkan sendiri oleh masing-masing satuan pendidikan, kemudian dilaksanakan dan dievaluasi oleh satuan pendidikan untuk mencapai tujuan pendidikan berdasarkan visi dan misi satuan pendidikan tersebut. KTSP dalam bentuk dokumen terdiri dari dua bagian yaitu; dokumen satu yang merupakan bagian dari kegiatan perencanaan madrasah yang mencakup seluruh program madrasah untuk masa waktu tertentu sesuai dengan perencanaan yang disusun oleh satuan pendidikan yang menggambarkan profil madrasah itu sendiri. Hal ini penting karena setiap satuan pendidikan harus mengevaluasi kurikulum yang telah disusun setiap tahunnya, sebelum kurikulum tersebut diberlakukan pada tahun berikutnya untuk memudahkan bagi satuan pendidikan mengetahui sejauhmana pencapaian selama satu tahun berjalan.

\section{Urgensi KTSP}

KTSP ini merupakan era baru dari kurikulum yang bersifat nasional menjadi kurikulum yang berbasis satuan pendidikan. Harapan dari KTSP ini adalah akan lahirnya kurikulum berbasis lokal yang sesuai dengan kebutuhan lokal dan dihasilkan oleh orang-orang lokal yang ada di satuan pendidikannya dengan mengacu kepada standar-standar nasional yang telah disusun oleh pusat.

KTSP adalah kurikulum yang diharapkan merupakan kurikulum yang terbaik dibanding dengan kurikulum yang pernah dikeluarkan sebelumnya, dan lebih bersifat prosfektif bila dibandingkan dengan kurikulum-kurikulum yang lain. KTSP lahir setelah berakhirnya KBK yang ditandai pula dengan dicabutnya penerapan kurikulum nasional, sekaligus pemerintah menggulirkan kebijakan yang sama sekali berbeda dengan perlakuan kurikulum sebelumnya.

\section{Konsep Implementasi KTSP}

Struktur KTSP terdiri dari dua dokumen, pertama, berisi tentang acuan pengembangan KTSP yang memuat latar belakang, tujuan dan prinsip pengembangan, tujuan pendidikan, struktur dan muatan kurikulum, kalender pendidikan. Kedua, berisi tentang silabus dan RPP. 15 
Implementasi Permendiknas RI Nomor 22 tahun 2006 tentang Standar Isi, khususnya KTSP, diartikan sebagai aktualisasi tertulis dalam bentuk pembelajaran. Sehubungan dengan implementasi Permendiknas tersebut, implementasinya bermuara pada persiapan dan proses pelaksanaan pembelajaran, yaitu perangkat pembelajaran dan pelaksanaan proses pembelajaran bagaimana agar isi kurikulum dapat diterima oleh peserta didik secara tepat dan optimal.16

Lebih lanjut dijelaskan bahwa implementasi kurikulum tingkat satuan pendidikan (KTSP) adalah suatu proses penerapan ide, konsep, dan kebijakan kurikulum dalam suatu aktivitas pembelajaran sehingga peserta didik menguasai seperangkat kompetensi tertentu sebagai hasil interaksi dengan lingkungan. Implemetasi kurikulum dapat juga diartikan sebagai aktualisasi kurikulum tertulis dalam bentuk pembelajaran. ${ }^{17}$

\section{METODE PENELITIAN}

\section{Jenis dan Lokasi Penelitian}

Jenis penelitian ini adalah kualitatif, yakni penelitian yang berupa memberikan gambaran tentang fenomena dan keadaan yang terjadi di lokasi berdasarkan pada kondisi ilmiah dari objek penelitian. ${ }^{18}$ Sedangkan lokasi penelitian terdapat pada enam madrasah yaitu Madrasah Aliyah YMPI Rappang, Madrasah Aliyah PP Al-Urwatul Wutsqa, Madrasah Aliyah DDI Tellu Limpoe, Madrasah Aliyah DDI Wanio, Madrasah Aliyah DDI Ma'had Pangkajene, dan Madrasah Aliyah Negeri Baranti.

\section{Sumber Data}

Adapun sumber data dalam penelitian ini adalah sebagai berikut; data primer dan data sekunder.

\section{Metode Pengumpulan Data}

Metode yang digunakan dalam pengumpulan data yaitu; observasi, wawancara, dokumentasi dan penelusuran referensi.

\section{Instrumen Penelitian}

Adapun instrumen yang digunakan dalam penelitian ini adalah; pedoman wawancara, field note atau catatan lapangan, dan dokumentasi.

\section{Teknik Pengolahan dan Analisis Data}

Data yang telah terkumpul kemudian diolah dengan analisis kualitatif interpretatif. Pengolahan data berlangsung bersamaan dengan proses pengumpulan data melalui tiga tahapan yaitu reduksi data, penyajian data, dan verifikasi data. Penarikan kesimpulan dilakukan dengan analisis induktif yaitu pembahasan dari hal-hal yang bersifat khusus kemudian disimpulkan melalui hal yang bersifat umum. Teknik analisis SWOT digunakan dalam rangka menentukan pilihan strategi dan upaya-upaya dalam peningkatan kualitas pendidikan di Madrasah Aliyah Kabupaten Sidrap. 


\section{Pengujian Keabsahan Data}

Pelaksanaan pengecekan keabsahan data didasarkan pada empat kriteria yaitu derajat kepercayaan (credibility), keteralihan (transferability), ketergantungan (dependability), dan kepastian (confirmability). Namun demikian dalam pengecekan keabsahan data dalam penelitian ini, penulis hanya menggunakan kriteria derajat kepercayaan (credibility), dan kepastian (confirmability), karena datanya sudah jenuh.

Di samping itu triangulasi adalah teknik pemeriksaan keabsahan data dengan memanfaatkan berbagai sumber di luar data sebagai hasil penelitian dapat dipertanggungjawabkan dimana peneliti berupaya untuk mengecek keabsahan data yang didapatkan dari salah satu sumber dengan sumber yang lain.

\section{HASIL PENELITIAN}

\section{Implementasi Kurikulum Tingkat Satuan Pendidikan (KTSP) dalam Proses Pembelajaran di Madrasah Aliyah Kabupaten Sidrap}

\section{Tingkat Penguasaan Guru terhadap Materi KTSP}

Tingkat penguasaan guru pada awal-awal diberlakukannya KTSP masih kurang. Hal ini ditunjukkan dengan masih sering terjadinya penafsiran yang berbeda di antara para guru dalam memahami pedoman atau petunjuk teknis kurikulum yang ada. Seperti dalam hal tata cara penuangan gagasan pembelajaran kreatif dalam RPP, penghitungan KKM, dan cara penilaian.

Kesulitan yang sering dijumpai adalah masih dominannya peran guru dalam proses pembelajaran di kelas, atau dengan kata lain masih rendahnya pemberdayaan siswa untuk menjadi lebih berperan aktif dalam proses pembelajaran sebagaimana tuntutan KTSP. Jika kondisinya demikian maka berarti guru belum beranjak dari kebiasaan yang dijalankan ketika masih menggunakan kurikulum lama.

\section{Kepatuhan Guru dalam Pengembangan Silabus}

Salah satu hal baru yang ada dalam KTSP adalah adanya kewenangan, atau kesempatan bagi para guru dalam kegiatan pengembangan silabus mata pelajaran yang diampunya. Memang dalam hal penentuan standar kompetensi dan kompetensi dasar sudah ditentukan secara nasional oleh Kementerian Pendidikan Nasional. Kesempatan yang dapat dilakukan guru untuk melakukan pengembangan silabus adalah dalam hal penentuan materi pokok/materi pelajaran, kegiatan pembelajaran/pengalaman belajar, indikator, penilaian (jenis dan bentuk tagihan), penetapan alokasi waktu yang dibutuhkan sesuai dengan kalender pendidikan sekolah, dan penentuan sumber/bahan/alat pelajaran.

\section{Kepatuhan Guru dalam Penyusunan Perangkat Pembelajaran}

Tugas seorang guru adalah di samping menyusun/mengembangkan silabus juga menyusun perangkat pembelajaran. Perangkat pembelajaran biasanya terdiri dari kalender pendidikan madrasah, analisis minggu efektif, program tahunan, progrm 
semester, silabus, rencana pelaksanaan pembelajaran, dan buku daftar nilai. Perangkat pembelajaran disusun pada awal semester atau awal tahun pelajaran yang bersangkutan.

Guru memiliki tingkat kepatuhan yang tinggi dalam hal kepatuhan dalam menyusun perangkat pembelajaran, meskipun dari segi kualitas masih bervariasi, tetapi setidaknya ini mencerminkan suatu kondisi yang cukup baik. Mereka tetap berusaha dengan segala keterbatasan yang dimilki madrasah.

\section{Penggunaan Metode Pembelajaran}

Pemakaian metode mengajar yang digunakan guru di Madrasah Aliyah Kabupaten Sidrap bervariasi. Ada yang masih menggunakan gaya lama dengan mengandalkan metode ceramah sebagai metode andalan, dan adapula yang sedikit demi sedikit sudah meninggalkan gaya lama dengan menyesuaikan metode dengan materi pelajaran. Ini dapat diketahui dari hasil wawancara penulis dengan beberapa orang guru yang mengajar di Madrasah Aliyah Kabupaten Sidrap. Tidak sedikit guru masih menggunakan metode ceramah dalam pembelajaran, padahal pembelajaran yang hanya menggunakan metode ceramah akan menghambat kreatifitas siswa dalam hal pemunculan kreasi-kreasi baru dan akan menghambat daya imajinasi peserta didik dalam mengembangkan pemikirannya.

Penggunaan metode pembelajaran guru di Madrasah Aliyah Kabupaten Sidrap dalam penerapan KTSP masih ada sebagian kecil guru yang belum menguasai metode mengajar dengan baik, sehingga dalam pelaksanaan pembelajaran di kelas hanya sekedar menggunakan metode tanpa memperhatikan karakteristik siswa, materi pelajaran.

\section{Pelaksanaan Pembelajaran Berbasis KTSP}

Pembelajaran berbasis KTSP merupakan suatu proses penerapan ide, konsep, dan kebijakan KTSP dalam suatu aktivitas pembelajaran, sehingga peserta didik menguasai seperangkat kompetensi tertentu, sebagai hasil interaksi dengan lingkungan.

a. Kegiatan Awal

Dalam pembelajaran jika persiapan matang sesuai dengan karakteristik kebutuhan, materi, metode, pendekatan, lingkungan serta kemampuan guru, maka hasilnya diasumsikan akan lebih optimal.

Pada umumnya guru di Madrasah Aliyah Kabupaten Sidrap mengadakan proses belajar mengajar dengan melakukan tahap persiapan dengan kegiatan appersepsi, menyampaikan kompetensi dasar atau tujuan yang akan dicapai serta mengadakan pre test sebelum masuk kepada program inti pembelajaran.

b. Kegiatan Inti (Pembentukan Kompetensi)

Guru Madrasah Aliyah di Kabupaten Sidrap mengenai pembentukan kompetensi pada bagian inti pembelajaran bahwa sebagian besar guru berusaha menggunakan pendekatan dan metode yang tepat agar kompetensi peserta didik terbentuk 
sesuai dengan apa yang tercantum dalam pencapaian, tetapi ada beberapa guru yang mengeluh karena terkadang kompetensi tidak tercapai secara maksimal karena kurangnya sarana dan prasarana di madrasahnya.

c. Kegiatan Penutup

Pada umumnya pelaksanaan pembelajaran diakhiri dengan post test. Untuk mengetahui apakah guru Madrasah Aliyah di kabupaten Sidrap melakukan kegiatan post test pada setiap akhir pembelajaran. Di bawah ini dipaparkan hasil wawancara penulis dengan beberapa informan berikut ini:"Setiap akhir pertemuan kami selalu melakukan kegiatan post test untuk melihat keberhasilan pembelajaran dan pembentukan kompetensi pada diri peserta didik."19

Faktor-faktor Pendukung dan Penghambat Peningkatan Kualitas Pendidikan di Madrasah Aliyah Kabupaten Sidrap

\section{Faktor Pendukung Peningkatan Kualitas Pendidikan di Madrasah Aliyah Kabupaten Sidrap}

a. Manajemen Kepala Madrasah

Kemampuan manajemen Kepala Madrasah Aliyah di Kabupaten Sidrap dalam membuat perencanaan, sebagaimana dikemukakan oleh salah seorang guru bahwa setiap ingin melakukan suatu kegiatan, selalu didahului dengan perencanaan. Setiap tahun ajaran baru, diadakan rapat kerja untuk menyusun program kerja satu tahun pelajaran ke depan. Demikian hal-hal lain yang dianggap penting.

Sebagai manajer, kepala madrasah memang dituntut untuk membuat perencanaan baik jangka pendek, jangka menengah, maupun jangka panjang dalam rangka peningkatan kualitas pendidikan di Madrasah Aliyah Kabupaten Sidrap.

Demikian pula kepala madrasah sebagai pemimpin organisasi, Kepala Madrasah Aliyah di Kabupaten Sidrap mampu menjalankan tugasnya dengan baik. Hal tersebut berdasarkan hasil wawancara dengan salah seorang guru madrasah aliyah bahwa salah satu kemampuan kepala madrasah kami adalah dalam pengorganisasian. Seperti membagi tugas kepada guru-guru berdasarkan keahlian masing-masing, misalnya menjadi pembina pramuka, pambina UKS, dan sebagainya. ${ }^{20}$

Dalam memberikan bimbingan, kepala madrasah memberikan teladan yang baik. Hasil wawancara dengan salah seorang guru di Madrasah Aliyah Kabupaten Sidrap bahwa kepala madrasah selalu memberikan teladan yang baik. Contohnya beliau selalu datang lebih awal dari staf dan bawahannya serta para siswa. Demikian pula biasanya pulang setelah staf dan bawahannya sudah kembali. ${ }^{21}$

b. Kurikulum

Kurikulum yang diterapkan di lembaga pendidikan, khususnya di Madrasah Aliyah Kabupaten Sidrap merupakan kurikulum desentralistik. Dalam hal ini, paradigma pendidikan di Indonesia saat ini sudah mengacu kepada penerapan Kuriku- 
lum Tingkat satuan Pendidikan (KTSP), artinya kurikulum harus mengacu kepada kebutuhan lokal. Di sinilah perlunya kesiapan sumber daya tenaga guru yang profesional dan juga sebagai ujung tombak dalam melaksanakan proses pembelajaran dan memegang peranan yang sangat menentukan keberhasilan peserta didik dalam melaksanakan proses pembelajarannya, bukan hanya pandai menstransfer pengetahuan secara kognitif, namun juga harus cerdas mengembangkan kurikulum yang efektif, efisien, fleksibel, relevan dan produktif. Guru yang yang profesional akan memiliki komitmen yang tinggi dan disertai dengan kemampuan sesuai dengan bidang keahliannya.

Dalam upaya peningkatan mutu pendidikan di Madrasah Aliyah Kabupaten Sidrap, ada satu hal yang perlu diperhatikan oleh pengelola Madrasah Aliyah bahwa motivasi terbesar bagi masyarakat untuk memasukkan putra-putrinya di Madrasah Aliyah karena materi pembelajarannya (kurikulumnya) sangat menitikberatkan kepada nilai-nilai keagamaan.

c. Kompetensi Guru dalam Melaksanakan Program Pembelajaran

Memang posisi guru sangat berpengaruh terhadap mutu pendidikan. Hal ini menurut hemat penulis disebabkan beberapa alasan logis bahwa guru merupakan pilar pokok dalam proses pembelajaran yang mempunyai tugas dan fungsi yaitu merancang model dan metode pembelajaran, memilih materi yang cocok dengan perkembangan siswa, mengajar dan membimbing siswa secara langsung baik dalam metode klasikal maupun individual, dan melakukan penilaian terhadap prestasi dan kompetensi siswa.

\section{d. Anggaran pendidikan (dana)}

Di Madrasah Aliyah Kabupaten Sidrap sumber dananya ada 2 yaitu dana pendidikan gratis dan dana bantuan operasional sekolah. Anggaran belanja madrasah aliyah yang kami terima hanya ada dua sumbernya, yaitu dana yang bersumber dari dana pendidikan gratis dan dana yang bersumber dari dana bantuan operasional sekolah (BOS). Itupun ada petunjuk teknis mengenai pengalokasian dana tersebut.

e. Optimalisasi kerjasama antara pihak madrasah dengan orang tua siswa

Salah satu bentuk kerjasama antara pihak madrasah dengan orang tua peserta didik adalah masalah pembinaan mental peserta didik, artinya aturan yang ada di madrasah harus di ketahui pihak orang tua peserta didik agar terjalin kerjasama dalam membina peserta didik. Kerjasama antara pihak madrasah dengan orang tua peserta didik belum optimal. Kerjasama yang berlangsung masih terbatas pada menghadiri rapat. Sementara peran yang lebih besar sebagai mitra madrasah yang diharapkan untuk mengembangkan madrasah ke arah yang lebih maju, masih sangat kurang.

\section{Faktor Penghambat Peningkatan Kualitas Pendidikan di Madrasah Aliyah Kabu- paten Sidrap serta solusinya}

Ada beberapa hambatan yang dihadapi oleh Madrasah Aliyah Kabupaten Sid- 
rap dalam peningkatan kualitas pendidikan, khususnya yang berkaitan dengan penyelenggaraan pendidikan. Di antara masalah tersebut adalah sebagai berikut:

a. Kualitas sarana dan prasarana

Upaya pengembangan madrasah adalah dengan mengembangkan pembangunan sarana dan prasarana yang dibutuhkan dalam rangka peningkatan kualitas pendidikan di Madrasah Aliyah Kabupaten Sidrap.

Solusi yang tepat untuk mengatasi masalah yang berkaitan dengan sarana parasarana, sebaiknya pihak madrasah mengalokasikan anggaran khusus tiap tahun agar sarana prasarana yang ada dapat berkualitas dan dapat menunjang tercapainya tujuan pembelajaran. Di samping itu itu, pihak madrasah juga harus melakukan hubungan baik dengan instansi terkait seperti Kementerian Agama supaya diberikan bantuan untuk pengadaan sarana prasarana yang dibutuhkan demi tercapainya kualitas pendidikan.

b. Kualitas guru dalam melaksanakan program pembelajaran

Salah satu faktor penghambat dalam peningkatan kualitas pendidikan di Madrasah Aliyah kabupaten Sidrap adalah masih adanya guru mengajar tidak sesuai dengan kualifikasi akademiknya.

Adapun solusi untuk meningkatkan kompetensi guru yang mengajarkan bidang studi yang tidak sesuai dengan kualifikasi pendidikannya adalah melalui pelatihan guru bidang studi dan memberdayakan MGMP (Musyawarah Guru Mata Pelajaran). Melalui pelatihan dan MGMP diharapkan permasalahan dapat teratasi. Kegiatan MGMP ini di bawah koordinasi KKM (Kelompok Kerja Madrasah) dan untuk setiap mata pelajaran dipimpin oleh guru senior yang ditunjuk oleh ketua KKM. Selain itu, sebaiknya pihak Pengawas dari Kementerian Agama dan Kepala Madrasah senantiasa mengadakan kegiatan supervisi, baik supervisi administrasi maupun supervisi kelas untuk mengetahui kompetensi guru dalam kegiatan proses belajar mengajar.

\section{c. Kesejahteraan Guru}

Rendahnya kesejahteraan guru merupakan salah satu hambatan dalam peningkatan kualitas pendidikan di Madrasah Aliyah Kabupaten Sidrap. Hal ini disebabkan oleh minimnya gaji yang diterima guru. Walaupun anggaran pendidikan di APBN sudah mencapai $20 \%$. Tapi belum terlalu memberikan pengaruh positif terhadap peningkatan kesejahteraan gaji. Maka, ada diantara guru Madrasah Aliyah di Sidrap yang mengajar di empat madrasah sekaligus.

Untuk mengatasi permasalahan tersebut, sebaiknya pihak madrasah membuka suatu usaha yang dapat membantu guru dalam mengatasi masalah dana. Sebagai contoh, madrasah membuka koperasi sekolah yang anggotanya dari guru-guru dalam lingkup madrasah itu sendiri. Solusi ini dapat membantu guru dalam mengatasi masalah dana, karena keuntungan dari koperasi tersebut kembalinya kepada anggotanya, dalam hal ini guru itu sendiri. 


\section{Analisis SWOT Peningkatan Kualitas Pendidikan di Madrasah Aliyah Kabupaten Sidrap}

Berdasarkan hasil penelitian di lapangan menunjukan bahwa upaya untuk meningkatkan kualitas pendidikan di Madrasah Aliyah Kabupaten Sidrap, para Kepala Madrasah Aliyah bersama stakeholder sebagian juga telah menerapkan pendekatan analisis SWOT. Berikut ini gambaran faktor kekuatan, kelemahan, peluang dan ancaman masing-masing Madrasah Aliyah:

Tabel 1.

Matriks Analisis SWOT dalam Upaya Peningkatan

Kualitas Pendidikan di Madrasah Aliyah Kabupaten Sidrap

\begin{tabular}{|c|c|c|c|c|}
\hline MADRASAH & KEKUATAN & KELEMAHAN & PELUANG & ANCAMAN \\
\hline $\begin{array}{l}\text { MA YMPI } \\
\text { Rappang }\end{array}$ & $\begin{array}{l}\text { 1. Pengelolaan } \\
\text { manajemen yang } \\
\text { akuntabel dan } \\
\text { transparan; } \\
\text { 2. Tenaga pendidik } \\
\text { rata-rata } \\
\text { berpendidikan } \\
\text { sarjana; } \\
\text { 3. Lingkungan yang } \\
\text { kondusif. }\end{array}$ & $\begin{array}{l}\text { 1. Sempitnya lokasi; } \\
\text { 2. Sarana prasarana } \\
\text { tidak lengkap; } \\
\text { 3. Kurangnya } \\
\text { sumber belajar; } \\
\text { 4. Kurangnya tenaga } \\
\text { pendidik yang } \\
\text { berstatus PNS; } \\
\text { 5. Masih ada guru } \\
\text { mengajarkan } \\
\text { bidang studi yang } \\
\text { tidak sesuai } \\
\text { dengan } \\
\text { jurusannya. }\end{array}$ & $\begin{array}{l}\text { 1. Faktor } \\
\text { kebijakan } \\
\text { pemerintah } \\
\text { yang } \\
\text { menguntung } \\
\text { kan } \\
\text { madrasah; } \\
\text { 2. Adanya } \\
\text { organisasi } \\
\text { profesi; } \\
\text { 3. Menerima } \\
\text { siswa banyak } \\
\text { karena } \\
\text { berdekatan } \\
\text { dengan MTs; } \\
\text { 4. Animo } \\
\text { masyarakat } \\
\text { tinggi. }\end{array}$ & $\begin{array}{l}\text { 1. Munculnya } \\
\text { sekolah } \\
\text { unggulan; } \\
\text { 2. Tuntutan } \\
\text { masyarakat } \\
\text { yang begitu } \\
\text { cepat sejalan } \\
\text { dengan } \\
\text { perkembanga } \\
\text { n zaman. }\end{array}$ \\
\hline $\begin{array}{l}\text { MA PP Al- } \\
\text { Urwatul } \\
\text { Wutsqa } \\
\text { Benteng }\end{array}$ & $\begin{array}{l}\text { 1. Tenaga pendidik } \\
\text { rata-rata } \\
\text { berpendidikan } \\
\text { sarjana; } \\
\text { 2. Siswa } \\
\text { diasramakan; } \\
\text { 3. Fasilitas gedung } \\
\text { belajar memadai; } \\
\text { 4. Dibekalinya siswa } \\
\text { dengan berbagai } \\
\text { macam } \\
\text { keterampilan } \\
\text { dalam kegiatan } \\
\text { pengembangan } \\
\text { diri. }\end{array}$ & $\begin{array}{l}\text { 1. Kurangnya tenaga } \\
\text { pendidik yang } \\
\text { berstatus PNS; } \\
\text { 2. Buku penunjang } \\
\text { masih jauh dari } \\
\text { memadai; } \\
\text { 3. Peralatan } \\
\text { laboratorium IPA } \\
\text { tidak lengkap. }\end{array}$ & $\begin{array}{l}\text { 1. Adanya } \\
\text { organisasi } \\
\text { profesi; } \\
\text { 2. Pengemba- } \\
\text { ngan } \\
\text { ketrampilan } \\
\text { tata boga dan } \\
\text { konveksi; } \\
\text { 3. Peningkatan } \\
\text { pola } \\
\text { pembinaan } \\
\text { siswa; } \\
\text { 4. Kemandirian } \\
\text { dan } \\
\text { kreativitas } \\
\text { siswa; } \\
\text { 5. Terciptanya } \\
\text { anak didik } \\
\text { yang mampu } \\
\text { di bidang } \\
\text { agama dan } \\
\text { umum. }\end{array}$ & $\begin{array}{l}\text { 1. Pemahaman } \\
\text { masyarakat } \\
\text { terhadapmad } \\
\text { rasah belum } \\
\text { benar } \\
\text { sehingga } \\
\text { cenderung } \\
\text { memasukkan } \\
\text { anaknya ke } \\
\text { sekolah } \\
\text { umum. }\end{array}$ \\
\hline
\end{tabular}




\begin{tabular}{|c|c|c|c|c|}
\hline $\begin{array}{l}\text { MA DDI Tellu } \\
\text { Limpoe }\end{array}$ & $\begin{array}{l}\text { 1. Manajemen } \\
\text { madrasah yang } \\
\text { akuntabel dan } \\
\text { transparan; } \\
\text { 2. Dimanfaatkan-nya } \\
\text { kebijakan } \\
\text { kurikulum lokal } \\
\text { yang tercermin } \\
\text { dalam kegiatan } \\
\text { pengembangan } \\
\text { diri dan mulok; } \\
\text { 3. Potensi sumber } \\
\text { daya manusia } \\
\text { yang ada dalam } \\
\text { madrasah tersebut. }\end{array}$ & $\begin{array}{l}\text { 1. Lokasi sempit; } \\
\text { 2. Tenaga guru PNS } \\
\text { hanya dua orang; } \\
\text { 3. Sarana dan } \\
\text { prasarana kurang } \\
\text { lengkap; } \\
\text { 4. Sumber belajar } \\
\text { kurang memadai. }\end{array}$ & $\begin{array}{l}\text { 1. Dukungan } \\
\text { pemerintah } \\
\text { dan } \\
\text { masyarakat } \\
\text { Islam sangat } \\
\text { kuat; } \\
\text { 2. Adanya } \\
\text { organisasi } \\
\text { profesi; } \\
\text { 3. Keluwesan } \\
\text { kebijakan } \\
\text { kurikulum } \\
\text { lokal untuk } \\
\text { optimalisasi } \\
\text { potensi dan } \\
\text { peluang } \\
\text { sesuai } \\
\text { kebutuhan di } \\
\text { lapangan; }\end{array}$ & $\begin{array}{l}\text { 1. Lokasi } \\
\text { sekolah } \\
\text { berada di } \\
\text { tengah- } \\
\text { tengah } \\
\text { penduduk } \\
\text { non Islam. }\end{array}$ \\
\hline $\begin{array}{l}\text { MA DDI } \\
\text { Wanio }\end{array}$ & $\begin{array}{l}\text { 1. Tenaga pendidik } \\
\text { rata-rata } \\
\text { berpendidikan } \\
\text { sarjana; } \\
\text { 2. Adanya budaya } \\
\text { warga madrasah } \\
\text { untuk } \\
\text { bermusyawarah } \\
\text { dalam mengambil } \\
\text { keputusan. }\end{array}$ & $\begin{array}{l}\text { 1. Sarana prasarana } \\
\text { kurang memadai; } \\
\text { 2. Kurangnya } \\
\text { promosi untuk } \\
\text { menumbuhkan } \\
\text { simpati } \\
\text { masyarakat; } \\
\text { 3. Kurangnya } \\
\text { sumber belajar; } \\
\text { 4. Sebagian guru } \\
\text { mengajar tidak } \\
\text { sesuai jurusannya. }\end{array}$ & $\begin{array}{l}\text { 1. Diberdaya- } \\
\text { kannya } \\
\text { organisasai } \\
\text { profesi; } \\
\text { 2. Dapat } \\
\text { menerima } \\
\text { siswa banyak } \\
\text { karena } \\
\text { berdekatan } \\
\text { dengan MTs. }\end{array}$ & $\begin{array}{l}\text { 1. Adanya } \\
\text { globalisasi } \\
\text { pendidikan } \\
\text { dan pasar } \\
\text { bebas; } \\
\text { 2. Rendahnya } \\
\text { kepercayaan } \\
\text { masyarakat } \\
\text { terhadap } \\
\text { produktivitas } \\
\text { madrasah. }\end{array}$ \\
\hline $\begin{array}{l}\text { MA DDI } \\
\text { Ma'had } \\
\text { Pangkajene }\end{array}$ & $\begin{array}{l}\text { 1. Kurikulum } \\
\text { lokalnya lebih } \\
\text { menekankan aspek } \\
\text { Pendidikan } \\
\text { Agama Islam; } \\
\text { 2. Tenaga pendidik } \\
\text { rata-rata } \\
\text { berpendidikan } \\
\text { sarjana. }\end{array}$ & $\begin{array}{l}\text { 1. Tenaga pendidik } \\
\text { yang berstatus } \\
\text { PNS kurang; } \\
\text { 2. Masi hada guru } \\
\text { mengajar tidak } \\
\text { sesuai dengan } \\
\text { jurusannya; } \\
\text { 3. Sarana prasarana } \\
\text { kurang lengkap; } \\
\text { 4. Buku } \\
\text { perpustakaan } \\
\text { kurng lengkap. }\end{array}$ & $\begin{array}{l}\text { 1. Terciptanya } \\
\text { anak didik } \\
\text { yang mampu } \\
\text { di bidang } \\
\text { umum } \\
\text { maupun } \\
\text { agama; } \\
\text { 2. Adanya } \\
\text { organisasi } \\
\text { profesi. }\end{array}$ & $\begin{array}{l}\text { 1. Banyaknya } \\
\text { sekolah yang } \\
\text { sejenis di } \\
\text { Kota } \\
\text { Pangkajene; } \\
\text { 2. Rendahnya } \\
\text { kepercayaan } \\
\text { masyarakat } \\
\text { terhadap } \\
\text { produktivitas } \\
\text { madrasah. }\end{array}$ \\
\hline MAN Baranti & $\begin{array}{l}\text { 1. Madrasah } \\
\text { berstatus negeri; } \\
\text { 2. Biaya operasional } \\
\text { madrasah } \\
\text { memadai; } \\
\text { 3. Potensi sumber } \\
\text { daya manusia }\end{array}$ & $\begin{array}{l}\text { 1. Lokasi sempit; } \\
\text { 2. Masih ada guru } \\
\text { mengajarkan } \\
\text { bidang studi tidak } \\
\text { sesuai jurusannya; } \\
\text { 3. Kurangnya } \\
\text { sumber belajar; } \\
\text { 4. Peralatan } \\
\text { laboratorium tidak } \\
\text { lengkap. }\end{array}$ & $\begin{array}{l}\text { 1. Dapat } \\
\text { menerima } \\
\text { siswa } \\
\text { banyak, } \\
\text { karena } \\
\text { berdekatan } \\
\text { dengan } \\
\text { MTs.N } \\
\text { Baranti; } \\
\text { 2. Adanya } \\
\text { organisasi } \\
\text { profesi. }\end{array}$ & $\begin{array}{l}\text { 1. Masyarakat } \\
\text { ke depan } \\
\text { kurang } \\
\text { berminat } \\
\text { memasukkan } \\
\text { anaknya } \\
\text { karena } \\
\text { fasilitas } \\
\text { gedung } \\
\text { kurang } \\
\text { memadai. }\end{array}$ \\
\hline
\end{tabular}

SumberData: Profil masing-masing Madrasah Aliyah di Kab. Sidrap Tahun 2013 
Berdasarkan matriks analisis SWOT Madrasah Aliyah di atas, jika dibandingkan antara teori dan praktek di lapangan, antara satu madrasah dengan madrasah yang lain, maka ditemukan suatu paradigma bahwa dalam menyusun faktor-faktor kekuatan, kelemahan, peluang dan ancaman diperlukan pemikiran yang matang sebab proses ini akan memiliki dampak yang serius dalam penyusunan perencanaan, pelaksanaan program serta proses evaluasi kegiatan suatu organisasi. Hal ini dapat dilihat pada MA YMPI Rappang yang menempatkan pengelolaan manajemen yang akuntabel dan transparan, tenaga pendidik rata-rata berpendidikan sarjana, lingkungan yang kondusif sebagai faktor kekuatan; sempitnya lokasi, sarana prasarana tidak lengkap, kurangnya sumber belajar, kurangnya tenaga pendidik yang berstatus PNS, masih ada guru mengajarkan bidang studi yang tidak sesuai dengan jurusannya sebagai faktor kelemahan, kemudian luas lokasi MA YMPI Rappang hanya 1175 m2;22 faktor kebijakan pemerintah yang menguntungkan madrasah, adanya organisasi profesi,menerima siswa banyak karena berdekatan dengan MTs, dan animo masyarakat tinggi sebagai faktor peluang; begitu juga faktor munculnya sekolah unggulan, tuntutan masyarakat yang begitu cepat sejalan dengan perkembangan zaman sebagai faktor ancaman.

\section{Bentuk Strategi Peningkatan Kualitas Pendidikan di Madrasah Aliyah Kabupaten Sidrap}

Pada dasarnya setiap Kepala Madrasah Aliyah di Kabupaten Sidrap telah menentukan strategi yang cukup bervariasi dan juga berupaya mencari jalan atau solusi guna peningkatan mutu pendidikannya sesuai dengan potensi dan lingkungan Madrasah Aliyah itu. Strategi peningkatan kualitas pendidikan di madrasah aliyah di Kabupaten Sidrap dapat dilihat pada tabel berikut ini.

Tabel 2.

Strategi Peningkatan Kualitas Pendidikan

di Madrasah Aliyah Kabupaten Sidrap

\begin{tabular}{|c|c|l|}
\hline NO. & \multicolumn{1}{|c|}{ MADRASAH ALIYAH } & \multicolumn{1}{c|}{ BENTUK STRATEGI } \\
\hline 1 & MA YMPI Rappang & $\begin{array}{l}\text { Mengubah pola pikir guru, revitalisasi MGMP, } \\
\text { meningkatkan disiplin semua warga madrasah, } \\
\text { melakukan kerjasama dengan pihak terkait dalam } \\
\text { pengadaan sarana dan pra sarana, menigkatkan } \\
\text { layanan perpustakaan, }\end{array}$ \\
\hline 2 & MA PP Al-Urwatul Wutsqa & $\begin{array}{l}\text { Melakukan kerjasama dengn pihak terkait dalam } \\
\text { pengadaan sarana dan prasarana, perbaikan } \\
\text { laboratorium, pemberdayaan laboratorium komputer, } \\
\text { mengintensipkan kelompok belajar di asrama siswa. }\end{array}$ \\
\hline 3 & MA DDI Tellu Limpoe & $\begin{array}{l}\text { Meningkatkan kualitas tugas kepala Madrasah, } \\
\text { mengadakan pembinaan terhadap siswa, guru dan } \\
\text { karyawan secara berkelanjutan, melaksanakan shalat } \\
\text { dhuhur secara berjamaah dan dilanjutkan latihan } \\
\text { pidato, menjalin kerjasama dengan lembaga terkait, } \\
\text { pengadaan buku-buku penunjang, membangun }\end{array}$ \\
\hline
\end{tabular}




\begin{tabular}{|c|l|l|}
\hline & & $\begin{array}{l}\text { komunikasi dengan lembaga terkait, kerjasama } \\
\text { madrasah dengan orang tua siswa, melibatkan seluruh } \\
\text { warga madrasah, komite madrasah dan lembaga- } \\
\text { lembaga lain dalam mengembangkan kurikulum } \\
\text { madrasah. }\end{array}$ \\
\hline 4 & MA DDI Wanio & $\begin{array}{l}\text { Melakukan kerjasama dengan orang tua siswa, men } \\
\text { sosialisasikan program madrasah kepada masyarakat, } \\
\text { mengadakan pembinaan kepada seluruh warga } \\
\text { madrasah, meningkatkan prestasi kerja kepala } \\
\text { madrasah. }\end{array}$ \\
\hline 5 & MA DDI Ma'had Pangkajene & $\begin{array}{l}\text { Meningkatkan kinerja kepala madrasah, memperbaiki } \\
\text { hubungan madrasah dengan masyarakat, Melibatkan } \\
\text { kepala madrasah, guru, komite sekolah, instansi } \\
\text { pemerintah dalam pengembangan kurikulum } \\
\text { madrasah. }\end{array}$ \\
\hline 6 & MAN Baranti & $\begin{array}{l}\text { Peningkatan kompetensi guru,peningkatan prestasi } \\
\text { akademik siswa, meningkatkan kualitas manajemen } \\
\text { kepala madrasah, meningkatkan layanan } \\
\text { perpustakaan, menambah sarana prasarana. }\end{array}$ \\
\hline
\end{tabular}

Sumber Data: Dokumen Visi, Misi, Tujuan dan Strategi Madrasah Aliyah Kabupaten Sidrap tahun 2013

\section{SIMPULAN}

Berdasarkan hasil penelitian dan pembahasan dapat disimpulkan beberapa hal pokok yang berkaitan dengan Strategi Peningatan Kualitas Pendidikan di Madrasah Aliyah Kabupaten Sidrap (Tinjauan Implementasi Kurikulum Tingkat Satuan Pendidikan) sebagai berikut:

1. Pada umumnya guru Madrasah Aliyah di Kabupaten Sidrap sudah mengimplementasikan Kurikulum Tingkat Satuan Pendidikan (KTSP) dalam proses pembelajaran sebagaimana yang tercantum dalam RPP yang sudah dikembangkan oleh masing-masing guru. Mulai dari kegiatan awal berupa apersepsi meliputi, apersepsi, kemudian motivasi meliputi pre test, dan menjelaskan kompetensi yang akan dicapai. Kemudian kegiatan inti berupa eksplorasi, elaborasi, dan konfirmasi, artinya di kegiatan inti ini diupayakan pembentukan kompetensi dengan menggunakan pendekatan dan metode yang bervariasi. Selanjutnya kegiatan penutup,meliputi mengadakan post test untuk mengetahui sejauhmana tingkat penguasaan peserta didik terhadap kompetensi yang ingin dicapai.

2. Sebagian guru tidak maksimal karena kondisi sarana yang tidak mendukung. Hal tersebut disebabkan oleh kurangnya sumber belajar yang memadai, seperti di beberapa Madrasah Aliyah yang penulis teliti kondisi laboratorium IPA sangat memprihatinkan. Artinya alat Laboratorium IPA kurang, dan disamping kondisi ruangannya tidak layak, juga faktor alat dan bahan praktikum kurang terpenuhi untuk pencapaian kompetensi tertentu.

3. Faktor pendukung dalam peningkatan kualitas pendidikan di Madrasah Aliyah Kabupaten Sidrap yaitu manajemen kepala madrasah, kurikulum, kompetensi guru dalam melaksanakan program pembelajaran, anggaran pendidikan/dana, optimalisasi kerjasama antara pihak madrasah dengan orang tua siswa/masyarakat. 
4. Faktor penghambat dalam peningkatan kualitas pendidikan di Madrasah Aliyah Kabupaten Sidrap adalah masih kurangnya sarana prasarana yang diperlukan dalam rangka memperlancar proses pembelajaran, masih adanya guru yang mengajar tidak sesuai dengan latar belakang pendidikannya, masih rendahnya kesejahteraan guru.

5. Solusi untuk mengatasi faktor penghambat dalam meningkatkan kualitas pendidikan di Madrasah Aliyah Kabupaten Sidrap adalah untuk meningkatkan kualitas sarana prasarana adalah sebaiknya pihak madrasah mengalokasikan anggaran agar sarana prasarana yang ada berkualitas yang dapat menunjang tercapainya tujuan pembelajaran, untuk meningkatkan kompetensi guru yang mengajar tidak sesuai dengan kualifikasi akademiknya, sebaiknya pihak madrasah mengikutkan guru dalam berbagai pelatihan, memberdayakan MGMP dan pengawas aktif memberikan bimbingan kepada guru melalui kegiatan supervisi, dan untuk mengatasi faktor kesejahteraan guru yang rendah, sebaiknya pihak madrasah membuka usaha sekolah yang dapat meningkatkan kesejahteraan guru, seperti koperasi sekolah.

6. Bentuk strategi peningkatan kualitas pendidikan di Madrasah Aliyah Kabupaten Sidrap adalah melalui delapan rencana strategis yaitu: peningkatan kualitas manajemen kurikulum dan program pengajaran, peningkatan kompetensi guru, peningkatan kesejahteraan guru, peningkatan prestasi akademik siswa, terpenuhinya kebutuhan sarana dan prasarana pendidikan yang mendukung pelaksanaan dan hasil belajar siswa, peningkatan kualitas pelaksanaan tugas kepala madrasah, peningkatan kualitas ketakwaan kepada Allah swt. serta akhlak mulia, dan meningkatkan manajemen hubungan madarasah dengan masyarakat.

\section{CATATAN AKHIR:}

1. Lihat A. Malik Fadjar, Reorientasi Pendidikan Islam, cet. I; Jakarta: Fajar Dunia, 1999, h. 156.

2. Murray Print, Curriculum Development and Design, Second Edition, New South Wales Australia: Allen \& Unwim, 1993, h. 19-23.

3. Kaeruddin dkk., Kurikulum Tingkat Satuan Pendidikan Konsep dan Implementasinya di Madrasah, Jogyakarta: Nuansa Aksara, 2007, h. 3.

4. E. Mulyasa, Kurikulum Tingkat Satuan Pendidikan, Bandung: Remaja Rosdakarya, 2006, h. 9.

5. Jonathan Salusu, Pengambilan Keputusan Stratejik untuk Organisasi Publik dan Organisasi Non-profil, Grasindo: Jakarta, 1996, h. 100.

6. Freddy Rangkuti, Strategi Riset Pemasaran, PT. Gramedia Pustaka Bersama: Jakarta, 2002, h. 14.

7. Nurkolis, Manajemen Berbasis Sekolah, cet. IV; Jakarta: PT. Grasindo, 2008, h. 72.

8. Minnah El-Widdah, et al., Kepemimpinan Berbasis Nilai dan Pengembangan Mutu Madrasah, cet. I; Bandung: Alfabeta, 2012, h. 105.

9. Minnah El-Widdah, et al., Kepemimpinan Berbasis Nilai dan Pengembangan Mutu Madrasah, h. 17.

10. Minnah El-Widdah, et al., Kepemimpinan Berbasis Nilai dan Pengembangan Mutu Madrasah, h.107.

11. Minnah El-Widdah, et al., Kepemimpinan Berbasis Nilai dan Pengembangan Mutu Madrasah, h.106. 
12. Minnah El-Widdah, et al., Kepemimpinan Berbasis Nilai dan Pengembangan Mutu Madrasah, h.107.

13. Minnah El-Widdah, et al., Kepemimpinan Berbasis Nilai dan Pengembangan Mutu Madrasah, h.107.

14. Direktorat Jenderal Pendidikan Islam Departemen Agama RI, Undang-Undang dan Peraturan Pemerintah RI tentang Pendidikan, h. 152.

15. Wina Sanjaya, Kurikulum dan Pembelajaran, Teori dan Praktek Pengembangan Kurikulum Tingkat Satuan Pendidikan (KTSP), Jakarta: Kencana, 2008, h. 152.

16. Abdul Majid dkk., Pendidikan Agama Islam Berbasis Kompetensi, cet. II; Bandung: PT. Remaja Rosdakarya, 2005, h. 15.

17. Kunandar, Guru Profesional, Implementasi Kurikulum Tingkat Satuan Pendidikan (KTSP) dan Sukses dalam Sertifikasi Guru, cet. VI; PT. Raja Grafindo Persada: Jakarta, h. 233.

18. M. Sayuti Ali, Metodologi Penelitian Agama, Pendekatan Teori dan Praktek cet. I; Jakarta: RajaGrafindo Persada, 2009, h. 59.

19. Kasmirah, Guru Matematika MA YMPI Rappang, Wawancara, Rappang, 16 Januari 2013.

20. Nurhayati, Guru MAN Baranti, Wawancara, Baranti, 11 Januari 2013.

21. Darmawati, Guru MA DDI Wanio, Wawancara, Wanio, 23 Januari 2013.

22. Kasmirah, Kepala MA YMPI Rappang, Wawancara, Rappang, 15 Januari 2013.

\section{DAFTAR PUSTAKA}

Ali, M. Sayuti, Metodologi Penelitian Agama, Pendekatan Teori dan Praktek cet. I; Jakarta: RajaGrafindo Persada, 2009.

Arifin, Anwar, Memahami Paradigma Baru Pendidikan Nasional dalam Undang-Undang sistem Pendidikan Nasional, cet. III; Jakarta: Dirjen Kelembagaan Agama Islam Departemen Agama RI, 2003.

Arifin, Muzayyin, Kapita Selekta Pendidikan Islam, cet. I; Jakarta: Bumi Aksara, 2003.

Arikunto, Suharsimi, Prosedur Penelitian, Jakarta: Rineka Cipta, 1993.

Azis, Abdul, dkk., Ensiklopedi Islam, cet. II; Jakarta: Ichtiar Baru Van Hoeve, 1994.

Azis, Abdul, Kesetaraan Status dan Masalah Mutu Lulusan Madrasah, Edukasi, no. 1 (JanuariMaret 2005.

Bungin, Burhan, Analisis Data Penelitian Kualitatif, Jakarta: RajaGrafindo Persada, 2005.

Departemen Agama Republik Indonesia; Direktorat Jenderal Kelembagaan Agama Islam, Pedoman Manajemen Berbasis Madrasah, Direktorat Jenderal Kelembagaan Agama Islam, 2003

Direktorat Jenderal Pendidikan Islam Departemen Agama RI, Undang-Undang dan Peraturan Pemerintah RI tentang Pendidikan.

Damopolii, Muljono, Pesantren Modern IMMIM Pencetak Muslim Modern, cet. I; Jakarta: RajaGrafindo Persada, 2011.

Fadjar, A. Malik, Reorientasi Pendidikan Islam, cet. I; Jakarta: Fajar Dunia, 1999.

Freeman, R. Edward, Strategic Management A. Stakeholder Approach, Edisi Indonesia; Jakarta: Pustaka Binaman Presindo, 1996.

Hamalik, Oemar, Pendidikan Guru Berdasarkan Pendekatan Kompetensi, cet. I; Jakarta: Bumi Aksara, 2002.

Kaeruddin, dkk., Kurikulum Tingkat Satuan Pendidikan Konsep dan Implementasinya di Madrasah, Jogyakarta: Nuansa Aksara, 2007.

Kunandar, Guru Profesional, Implementasi Kurikulum Tingkat Satuan Pendidikan (KTSP) dan Sukses dalam Sertifikasi Guru, cet. VI; PT RajaGrafindo Persada: Jakarta. 
Majid, Abdul, dkk., Pendidikan Agama Islam Berbasis Kompetensi, cet. II; Bandung: PT Remaja Rosdakarya, 2005.

Mulyasa, E., Kurikulum Tingkat Satuan Pendidikan, Bandung: Remaja Rosdakarya, 2006.

Nurkolis, Manajemen Berbasis Sekolah, cet. IV; Jakarta: PT Grasindo, 2008.

Print, Murray, Curriculum Development and Design, Second Edition, New South Wales Australia: Allen \& Unwim, 1993.

Rangkuti, Freddy, Strategi Riset Pemasaran, PT Gramedia Pustaka Bersama: Jakarta, 2002.

Salusu, Jonathan, Pengambilan Keputusan Stratejik untuk Organisasi Publik dan Organisasi Nonprofil, Grasindo: Jakarta, 1996.

Sanjaya, Wina, Kurikulum dan Pembelajaran, Teori dan Praktek Pengembangan Kurikulum Tingkat Satuan Pendidikan (KTSP), Jakarta: Kencana, 2008.

El-Widdah, Minnah, et al., Kepemimpinan Berbasis Nilai dan Pengembangan Mutu Madrasah, cet. I; Bandung: Alfabeta, 2012. 